\title{
SEED DISPERSAL PATTERNS IN TWO CLOSELY RELATED HOWLER MONKEY SPECIES (ALOUATTA PALLIATA AND A. PIGRA): A PRELIMINARY REPORT OF DIFFERENCES IN FRUIT CONSUMPTION, TRAVELING BEHAVIOR, AND ASSOCIATED DUNG BEETLE ASSEMBLAGES
}

\section{Katherine R. Amato ${ }^{1 *}$, Alejandro Estrada ${ }^{2}$}

\author{
${ }^{1}$ Program in Ecology, Evolution, and Conservation Biology, University of Illinois - Urbana/Champaign, email: amato1@illinois. \\ edu, *Author for correspondence \\ ${ }^{2}$ Laboratorio de Primatología, Estación de Biología Tropical Los Tuxtlas, Instituto de Biología, Universidad Nacional \\ Autónoma de México, email: aestrada@primatesmx.com
}

\begin{abstract}
Two-phased seed dispersal by primates and dung beetles is crucial for tropical rainforest regeneration. Two species of howler monkey exist in the tropical rainforests of southern Mexico: the mantled howler monkey (Alouatta palliata), and the black howler monkey (A. pigra). Differences between these species in foraging and traveling behavior, as well as associated dung beetle assemblages, may influence seed dispersal patterns. In this paper we present the results of a preliminary four-month study comparing the above aspects between a group of $A$. palliata $(\mathrm{N}=15)$ in Los Tuxtlas, Veracruz and a group of $A$. pigra $(\mathrm{N}=7)$ in Palenque National Park, Chiapas, Mexico. We observed each group in alternating months using focal sampling, fecal examination, and trapping of dung beetles. Results showed that the $A$. palliata group consumed more mature fruit, but both groups dispersed similar numbers of seeds over the study period (ca. 13,000 seeds). The total number of seed species collected from the feces of the $A$. palliata group was lower than for the $A$. pigra group ( 13 vs. 31 species). The $A$. palliata group had a larger home range (33 vs. 6.25 ha) and average day range ( 202 vs. $126 \mathrm{~m}$ ). More dung beetles from more species were associated with the $A$. palliata group ( 357 v. 99 beetles, 16 v. 8 species). The $A$. palliata group attracted more ballrolling dung beetles $(75.1 \%$ of total), while the $A$. pigra group attracted more burrowers ( $80.8 \%$ of total). Our results suggest important differences between black and mantled howler monkeys of southern Mexico as seed dispersers and highlight the need to consider foraging and ranging patterns, as well as associated secondary dispersers, when assessing seed dispersal by primates.
\end{abstract}

Key Words: howler monkeys, seed dispersal, A. palliata, A. pigra, dung beetles, Mexico

\section{Resumen}

La dispersión por primates y cucarrones estercoleros es crucial para la regeneración del bosque tropical. Dos especies de monos aulladores existen en los bosques lluviosos del sur de Mexico: el mono aullador de manto (Alouatta palliata), y el mono aullador negro (A. pigra). Las diferencias entre estas dos especies en el comportamiento de forrajeo y desplazamiento, así como los ensamblajes de cucarrones estercoleros asociados, pueden influenciar los patrones de dispersión de semillas. En este artículo presentamos los resultados de un estudio preliminar de cuatro meses, comparando estos aspectos entre un grupo de $A$. palliata $(\mathrm{N}=15)$ en Los Tuxtlas, Veracruz, y un grupo de $A$. pigra $(\mathrm{N}=7)$ en el Parque Nacional Palenque, Chiapas, Mexico. Observamos cada grupo durante meses alternos utilizando el muestreo focal, examinando muestras de heces, y coleccionando cucarrones estercoleros. Los resultados mostraron que el grupo de $A$. palliata consumió más frutos maduros, pero los grupos de ambas especies dispersaron un número similar de semillas durante el período de estudio (ca. 13,000 semillas). El número total de especies de semillas coleccionadas de las heces del grupo de $A$. palliata fue más bajo que aquel para el grupo de $A$. pigra (13 vs. 31 especies). El grupo de $A$. palliata tuvo un área de rango vital más grande (33 vs. 6.25 ha) así como un recorrido diario promedio mayor (202 vs. $126 \mathrm{~m}$ ). Más cucarrones estercoleros de más especies estuvieron asociados con el grupo de $A$. palliata (357 v. 99 cucarrones, 16 v. 8 especies). El grupo de $A$. palliata atrajo más cucarrones estercoleros peloteros $(75.1 \%$ del total), mientras que el grupo de $A$. pigra atrajo más estercoleros cavadores $(80.8 \%$ del total). Nuestros resultados sugieren importantes diferencias entre los aulladores negros y aulladores de manto del sur de Mexico como dispersores de semillas y resaltan la necesidad de considerar el forrajeo y los patrones de movimiento, así como los dispersores secundarios asociados, cuando se evalúa la dispersión de semillas por parte de primates.

Palabras Clave: monos aulladores, dispersión de semillas, A. palliata, A. pigra, cucarrones estercoleros, Mexico 


\section{Introduction}

Large frugivorous primates are important seed dispersers for many tropical tree species (Link and Di Fiore 2006). Although birds disperse a larger number of seeds, primates disperse the seeds of twice as many plant species as birds via endozoochory (Clark et al. 2001), and their ecological services are critical for recruitment of many medium- and large-seeded plant species (Ponce-Santizo and Andresen 2006; Stevenson and Aldana 2008; Stoner et al. 2007). Additionally, many seeds ingested by primates undergo twophase dispersal. Dung beetles attracted to primate feces act as secondary dispersal agents by accidentally burying seeds along with feces at the deposition site or, if the beetles are ball-rollers, a short distance away (Vander Wall and Longland 2004; Vulinec et al. 2006). This behavior may allow some seeds to escape post-dispersal predation and may provide ideal microclimatic conditions, increasing the probability of seed germination and establishment (Nichols et al. 2008; Vander Wall and Longland 2004; Vulinec and Lambert 2009; Vulinec et al. 2006).

Two species of howler monkeys exist in the tropical forests of southern Mexico. The mantled howler monkey (Alouatta palliata), which is found throughout Central America and into western South America, and the black howler monkey (A. pigra), which is endemic to the area shared by Mexico, Belize, and Guatemala (Ford 2006; Rylands et al. 2006). Behavioral studies generally report similar resource use and activity budgets for $A$. palliata and $A$. pigra (Estrada 1984; Pavelka and Knopff 2004), and the reported values of species richness for dung beetle populations associated with each primate species (A. palliata: 33 sp.; A. pigra: 29 sp.) are also similar (Estrada and Coates-Estrada 2002; PonceSantizo and Andresen 2006).

Many seed dispersal studies assume that all primates disperse seeds similarly (Gross-Camp et al. 2009; NunezIturri et al. 2008), and only a few studies compare seed dispersal by closely related primate species in similar habitats (Knogge and Heymann 2003; Stevenson et al. 2002). However, based on differences in average body size (A. palliata, males: $4.5-9.8 \mathrm{~kg}$, females: $3.1-7.6 \mathrm{~kg}$; $A$. pigra, males: 11.1-11.6 kg, females: 6.2-6.6 kg, (Ford and Davis 1992) and group size (A. palliata, 5-16 indiv., average: 8 indiv.; A. pigra, 2- 12 indiv., average: 4 individuals, (Di Fiore and Campbell 2007; Van Belle and Estrada 2008), A. palliata and $A$. pigra may differ in seed dispersal patterns. In this paper, we report results from a short comparative study of A. palliata and A. pigra aimed at documenting daily travel patterns, seed species dispersed, and dung beetle species associated with howler monkey feces.

\section{Methods}

\section{Data collection}

The mantled howler monkey (A. palliata) was studied in a 2000 ha segment of the Los Tuxtlas Biosphere Reserve in the region of Los Tuxtlas, Veracruz $\left(18^{\circ} 35^{\prime} 08.63^{\prime \prime} \mathrm{N}\right.$, $\left.95^{\circ} 04^{\prime} 26.99^{\prime \prime} \mathrm{W}\right)$, and the black howler monkey (A. pigra) was studied in Palenque National Park (PNP) $(-1800$ ha; $\left.17^{\circ} 29^{\prime} 12.02^{\prime \prime} \mathrm{N}, 92^{\circ} 03^{\prime} 01.05^{\prime \prime W}\right)$, Chiapas, both in southeast Mexico (Fig. 1). At both sites vegetation is classified as tall, tropical rainforest, and the altitudinal gradient ranges from $150 \mathrm{~m}$ to $500 \mathrm{~m}$ above sea level (Estrada 1984; Estrada et al. 2002). Sampling was conducted in areas of continuous forest at both sites. Focal samples were collected for one group of $A$. palliata $(\mathrm{N}=15)$ in Los Tuxtlas during March and May 2008, and for one group of $A$. pigra $(\mathrm{N}=7)$ in PNP during February and April 2008 for eighteen days each month. We collected 135 and 120 hrs of continuous focal samples on the $A$. palliata group and $A$. pigra group, respectively. To control for differences in group size and observation time, all focal data for each species were pooled across individuals and an average focal observation for each species was calculated. We assumed that by alternating monthly observations for each howler group/species during the dry season (Estrada et al. 2002; Estrada and Coates-Estrada 2002) at both sites that, to a certain extent, we compensated for seasonal effects in the data. Additionally, sampling took place during the high-fruit season in both forests. In Los Tuxtlas, $A$. palliata consumes the most mature fruit between March and October (Estrada 1984; Estrada and Coates-Estrada 1991), and in PNP, A. pigra consumes the most mature fruit between March and July (Estrada and Muñoz, unpublished data). Studies of dung beetles in Los Tuxtlas have demonstrated that dung beetle populations during the same months (Estrada et al. 1993). No previous studies have examined the dung beetle population at PNP, but because the annual rainfall profile generally matches that observed at Los Tuxtlas (Estrada and Muñoz, unpublished data), seasonal fluctuations in the dung beetle population are likely similar to those in Los Tuxtlas.

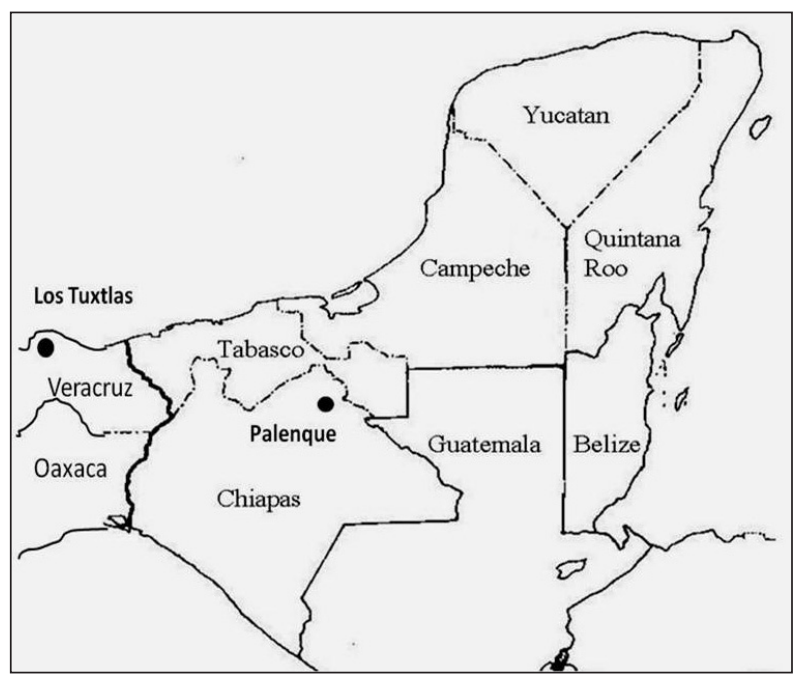

Figure 1. Location of study sites in southeast Mexico. 
Focal samples were completed between 06:00 and 15:00 hrs each day to allow time for fecal sample processing. Each sample lasted between five and $15 \mathrm{~min}$ (avg.: $14 \mathrm{~min} \pm 3$ ). Focal individuals were chosen in a random order, and sampling was rotated until all individuals in the group were sampled. For each sample, the occurrence and duration of feeding (ingestion of plant material) and travel (group movement from one tree to another) activity was recorded. During feeding observations, the type of plant part ingested was recorded and identified to the species level. A scaled topographic map was used to estimate the distances traversed by the howlers. Total group biomass was estimated using the median body weight for each species (Ford and Davis 1992), and group biomass per hectare was calculated using the home range estimate from each map. Both groups were known to have only one neighboring group, and home range overlap was negligible. Only two $A$. palliata and three $A$. pigra intergroup interactions were observed during the study period.

Fecal samples were collected each day and examined for seeds. Seeds collected from the fecal samples were counted and, when possible, identified to species by comparison to the seed collection at the Los Tuxtlas field station and the National Herbarium housed at the Institute of Biology of the Universidad Nacional Autónoma de México. In the case of seeds $<1 \mathrm{~mm}$ in length occurring at high densities, the number of seeds in the sample was estimated by sample volume (seeds $/ 30 \mathrm{~mL}$ feces).

Sampling of dung beetles was conducted at each site within the home range of the study groups using 10 pit-fall traps $(15 \mathrm{~cm}$ in height $\times 5 \mathrm{~cm}$ width) baited with $60 \mathrm{~g}$ of feces from the howler species present. Traps were placed at $50 \mathrm{~m}$ intervals along a $500 \mathrm{~m}$ sinuous transect (Larsen and Forsyth 2005) and remained there for $24 \mathrm{hr}$. The traps were located about $1 \mathrm{~m}$ off of the main trail in ecologically similar locations at each site. Sampling was repeated three times per months at each site, and three distinct transects were used each month in an effort to fully represent each group's home range. Dung beetles encountered in the traps were counted and, when possible, identified to species by comparison of specimens with the dung beetle collection at the Los Tuxtlas field station.

\section{Data analysis}

Because individuals were sampled randomly, and no individual was sampled two times consecutively, focal samples were assumed to be independent. The proportion of time spent traveling and feeding on each resource during a given focal sample were compared between groups using a Kruskal-Wallis test with a Bonferroni correction (R Software). The amount of time dedicated to feeding on each mature fruit species was expressed as a percent of total maturefruit consumption time. Total average distance traveled per day during the observation period was compared between howler monkey groups using a two-tailed, one-way ANOVA, after log-transformation (JMP 7.0). Since tree crowns as large as $50 \mathrm{~m}$ have been measured in the tropical forests of southeastern Mexico (Estrada and Coates-Estrada 1984), only daily movements of $50 \mathrm{~m}$ or more were considered as contributions to seed dispersal. Home range was calculated by using a gridded topographic map $(50 \times$ $50 \mathrm{~m}$ ) of the study site to count the number of quadrants in which the group was present during monthly observations.

The number of seeds dispersed per day and the number of seeds per milliliter of fecal sample were compared using a two-tailed, one-way ANOVA (JMP 7.0). A chi-squared test was used to compare the total number of seeds dispersed, the number of large and small seeds dispersed, the total volume of feces produced, and the estimated biomass of each group. Shannon's diversity index $\left(\mathrm{H}^{\prime}\right)$ and Sorenson's similarity quotient were calculated to compare the dung beetle populations collected at each study site (Estrada and Coates-Estrada 2002).

\section{Results}

On average, both howler groups spent a similar percentage of time feeding on fruit during a focal sample (A. palliata: $9.27 \% \pm 5.05$, A. pigra: $11.21 \% \pm 4.76 ; \chi^{2}=0.81$, $\mathrm{df}=1, \mathrm{p}=0.37$; Table 1). Consumption of mature fruit accounted for $8.54 \% \pm 4.94$ of an average focal sample for the $A$. palliata group and $5.28 \% \pm 2.96$ for the $A$. pigra

Table 1. Average percent time individuals from the $A$. palliata and $A$. pigra groups spent consuming fruit and leaves during any given focal sample ( $\mathrm{N}=584$ and 547 focal samples, respectively). Comparisons between groups were performed using a Kruskal-Wallis test with Bonferroni correction. Asterisks indicate significant $\mathrm{p}$ values. All medians $=0 \%$.

\begin{tabular}{|c|c|c|c|c|c|c|c|}
\hline & \multicolumn{2}{|c|}{ Alouatta palliata } & \multicolumn{2}{|c|}{ Alouatta pigra } & \multicolumn{3}{|c|}{ Kruskal-Wallis } \\
\hline & Average & SD & Average & SD & $\chi^{2}$ & df & $\mathrm{p}$ \\
\hline Fruit & 9.27 & 5.056 & 11.21 & 4.76 & 0.80 & 1 & 0.37 \\
\hline Mature fruit & 8.54 & 4.94 & 5.28 & 2.96 & 2.69 & 1 & 0.10 \\
\hline Young fruit & 0.73 & 1.29 & 5.93 & 3.28 & 11.53 & 1 & $0.00069^{*}$ \\
\hline Leaves & 2.66 & 2.06 & 10.24 & 4.89 & 11.31 & 1 & $<0.00077^{*}$ \\
\hline Mature leaves & 0.46 & 0.72 & 1.86 & 2.30 & 2.75 & 1 & 0.097 \\
\hline Young leaves & 2.21 & 1.81 & 8.38 & 2.96 & 11.35 & 1 & $<0.00076^{*}$ \\
\hline
\end{tabular}


group (Table 1). During the study period the $A$. palliata group consumed the mature fruits of a total of nine species (Table 2), while the $A$. pigra group consumed the mature fruits of four species (Table 3). A. palliata group was observed consuming mostly Ficus species (Moraceae) (F. pertusa: $17.33 \%$ of mature-fruit feeding time, $F$ colubrinae: 15.30\%, F. insipida: $15.65 \%$ ) (Table 2), and A. pigra group mostly P. armata (Moraceae) (43.04\%) (Table 3).

Overall, fewer fecal samples were collected from the A. palliata group $(156$ samples $=3230 \mathrm{~mL})$ than from the A. pigra group (167 samples $=4800 \mathrm{ml}, \chi^{2}=307.0, \mathrm{df}=1$, $p=0.0001$ ). More seeds were collected from the fecal samples of the $A$. palliata group (13,756 seeds) than the A. pigra group (13,162 seeds; $\left.\chi^{2}=13.1, \mathrm{df}=1, p=0.0003\right)$, and fecal samples contained seeds from 13 and 31 species, respectively (Tables 2 and 3). Based on both focal and fecal sample data, the $A$. palliata group utilized 18 fruit species during the study period, and the $A$. pigra group utilized 33 . The majority of seeds recovered from both groups were from Ficus species (A. palliata, F. engeniafolia: $43.7 \%$ of Ficus seeds, A. pigra, F. sp. 1: 43.9 \%; Table 2, 3). However, the seeds collected from the two groups varied in size.
The largest seed found in fecal samples of $A$. palliata was $21 \mathrm{~mm}$ in length (unknown sp. 10) (Table 2), and the largest seed found in fecal samples of $A$. pigra was $40 \mathrm{~mm}$ in length (Inga sp. 1) (Table 3). Most seeds measuring $<3 \mathrm{~mm}$ belonged to the Ficus genus, and both howler groups expelled more seeds measuring $<3 \mathrm{~mm}$ than seeds measuring $>3 \mathrm{~mm}$ (A. palliata: $\chi^{2}=13022.2, \mathrm{df}=1, p<0.0001$; A. pigra: $\left.\chi^{2}=10831.2, \mathrm{df}=1, p<0.0001\right)$. However, the percent of total seeds deposited that were greater than 3 mm was smaller for the $A$. palliata group (1.3\%) than for the $A$. pigra group (4.6\%). These seeds belonged to four and 11 plant species, respectively. Feces from $A$. palliata contained slightly more seeds $/ \mathrm{ml}$ than those from $A$. pigra $\left(4 \pm 4\right.$ seeds $/ \mathrm{ml}$ and $2 \pm 3$ seeds $/ \mathrm{ml}$ respectively; $\mathrm{F}_{1,64}=7.63$, $p=0.007)$. However, both groups deposited similar numbers of seeds per day (A. palliata: $458 \pm 643( \pm \mathrm{SD})$, A. pigra: $\left.376 \pm 1030( \pm \mathrm{SD}) ; \mathrm{F}_{1,64}=0.15, \mathrm{p}=0.70\right)$.

The $A$. palliata group used a larger home range (12.5 ha) than the $A$. pigra group ( $6.25 \mathrm{ha}$ ) during the study period. Therefore, despite differences in group size, both groups accounted for similar howler monkey biomass/ha (A. palliata: $6.1 \mathrm{~kg} / \mathrm{ha}$, A. pigra: $\left.7.7 \mathrm{~kg} / \mathrm{ha}, \chi^{2}=0.185, \mathrm{df}=1, \mathrm{p}=0.33\right)$.

Table 2. List of seed species collected from howler fecal samples and mature fruit species howlers were observed consuming in Los Tuxtlas (A. palliata). Quantity of seeds from each plant species is reported using the absolute number and the percent of total seeds collected in each site. Also shown is the percent of mature-fruit feeding time howlers devoted to consuming a particular species. Species recorded from focal samples only are highlighted in bold. Values for seed size marked with an asterisk were estimated in the field. Values without an asterisk were obtained from Croat (1978).

\begin{tabular}{|c|c|c|c|c|c|c|c|}
\hline Species/Morphotype & Family & Lifeform & $\begin{array}{l}\text { Type of } \\
\text { Fruit }\end{array}$ & $\begin{array}{c}\text { Percent } \\
\text { Feeding Time }\end{array}$ & $\begin{array}{l}\text { Number } \\
\text { Seeds }\end{array}$ & $\begin{array}{l}\text { Percent Total } \\
\text { Seeds }\end{array}$ & $\begin{array}{l}\text { Seed Size } \\
\quad(\mathrm{mm})\end{array}$ \\
\hline Brosimum alicastrum & Moraceae & Tree & drupe & 10.96 & - & - & 15 \\
\hline Coussapoa purpusii & Moraceae & Tree & drupe & drupe & - & - & - \\
\hline Ficus pertusa & Moraceae & Tree & syconium & 17.33 & - & - & $<1^{*}$ \\
\hline Ficus sp. & Moraceae & Tree & syconium & 2.65 & - & - & $<1^{*}$ \\
\hline Ficus tecolutensis & Moraceae & tree & syconium & 7.07 & - & - & $<1^{*}$ \\
\hline sp. 1 & - & - & - & 0.53 & - & - & - \\
\hline Ficus engeniaefolia & Moraceae & tree & syconium & - & 5679 & 43.70 & $<1^{*}$ \\
\hline Ficus colubrinae & Moraceae & tree (strangler) & syconium & 15.30 & 3925 & 30.20 & $1^{*}$ \\
\hline Ficus insipida & Moraceae & tree & syconium & 15.65 & 1647 & 12.67 & $2^{*}$ \\
\hline Ficus petenensis & Moraceae & tree (strangler) & syconium & - & 1462 & 11.25 & $1^{*}$ \\
\hline Cecropia obstusifolia & Cecropiaceae & tree & drupe & 0.88 & 808 & 6.22 & $2^{*}$ \\
\hline Poulsenia armata & Moraceae & tree & aggregate & 15.83 & 116 & 0.89 & $4,10^{*}$ \\
\hline sp. 10 & - & - & - & - & 37 & 0.28 & $21^{*}$ \\
\hline sp. 5 & & & & & 33 & 0.25 & \\
\hline sp. 11 & - & - & - & - & 26 & 0.20 & $3^{*}$ \\
\hline Cynometra vetusa & Fabaceae & tree & drupe & 8.66 & 16 & 0.12 & $13^{*}$ \\
\hline Smilax sp.1 & Smilicaceae & vine & berry & - & 4 & 0.03 & $8^{*}$ \\
\hline sp. 13 & - & - & - & - & 2 & 0.02 & $3^{*}$ \\
\hline sp. 12 & & & & & 1 & 0.01 & \\
\hline $\begin{array}{l}\text { Total Species = } 18 \\
\text { Total Seed }\end{array}$ & & & & & 13,756 & & \\
\hline
\end{tabular}


The average proportion of time spent traveling also did not differ between groups (A. palliata: $0.058 \pm 0.055$, A. pigra: $\left.0.069 \pm 0.018 ; \chi^{2}=2.23, \mathrm{df}=1, \mathrm{p}=0.13\right)$. During the study period, the $A$. palliata group traveled less than $50 \mathrm{~m}$ on 12 of the 34 days during which it was followed. The A. pigra group traveled less than $50 \mathrm{~m}$ on 15 of 34 days. Excluding these days, the $A$. palliata group had a marginally significantly larger day range $(202 \pm 149 \mathrm{~m}$, range:
$50-630 \mathrm{~m})$ than the $A$. pigra group $(127 \pm 66 \mathrm{~m}$, range $\left.50-250 \mathrm{~m} ; \mathrm{F}_{1,40}=4.15, p=0.048\right)$.

At Los Tuxtlas, pit-fall traps captured 357 beetles belonging to 16 species (avg beetles/session $=59.50 \pm 78.69$ ), while in Palenque they captured 99 beetles belonging to eight species (avg. beetles/session $=16.50 \pm 12.68)$ (Table 4). There was some evidence for higher dung beetle species

Table 3. List of seed species collected from howler fecal samples and mature fruit species howlers were observed consuming in Palenque (A. pigra). Quantity of seeds from each plant species is reported using the absolute number and the percent of total seeds collected in each site. Also shown is the percent of mature-fruit feeding time howlers devoted to consuming a particular species. Species recorded from focal samples only are highlighted in bold. Values for seed size marked with an asterisk were estimated in the field. Values without an asterisk were obtained from Croat (1978).

\begin{tabular}{|c|c|c|c|c|c|c|c|}
\hline Species/Morphotype & Family & Lifeform & $\begin{array}{l}\text { Type of } \\
\text { Fruit }\end{array}$ & $\begin{array}{c}\text { Percent } \\
\text { Feeding Time }\end{array}$ & $\begin{array}{l}\text { Number } \\
\text { Seeds }\end{array}$ & $\begin{array}{l}\text { Percent Total } \\
\text { Seeds }\end{array}$ & $\begin{array}{l}\text { Seed size } \\
(\mathrm{mm})\end{array}$ \\
\hline Brosimum alicastrum & Moraceae & tree & drupe & 13.92 & - & - & 15 \\
\hline Ficus sp. 1 & Moraceae & - & syconium & - & 5599 & 43.87 & $<1^{*}$ \\
\hline Ficus sp. 9 & Moraceae & - & syconium & - & 3152 & 24.70 & $<1^{*}$ \\
\hline Ficus colubrinae & Moraceae & tree (strangler) & syconium & 30.87 & 2670 & 20.92 & $1^{*}$ \\
\hline Poulsenia armata & Moraceae & tree & aggregate & 43.04 & 459 & 3.60 & $4,10^{*}$ \\
\hline Ficus pertusa & Moraceae & tree (strangler) & syconium & - & 425 & 3.33 & $<1^{*}$ \\
\hline Ficus insipid & Moraceae & tree & syconium & - & 379 & 2.97 & $2^{*}$ \\
\hline sp. 2 & - & - & - & - & 140 & 1.10 & - \\
\hline Ficus sp. 3 & Moraceae & - & syconium & - & 69 & 0.54 & $1^{*}$ \\
\hline Ficus sp. 2 & Moraceae & - & syconium & - & 40 & 0.31 & $1^{*}$ \\
\hline Ficus petenensis & Moraceae & tree (strangler) & syconium & - & 38 & 0.30 & $1^{*}$ \\
\hline Cecropia obstusifolia & & & & & 36 & 0.28 & \\
\hline sp. 6 & - & - & - & - & 33 & 0.26 & $8^{*}$ \\
\hline sp. 3 & - & - & - & - & 17 & 0.13 & - \\
\hline Ficus engeniaefolia & Moraceae & tree & syconium & - & 15 & 0.12 & $<1^{*}$ \\
\hline Ficus sp. 4 & Moraceae & - & syconium & - & 14 & 0.11 & $<1^{*}$ \\
\hline sp. 1 & - & - & - & - & 13 & 0.10 & $15^{*}, 34^{*}$ \\
\hline Cynometra vetusa & Fabaceae & tree & drupe & 12.15 & 11 & 0.09 & $13^{*}$ \\
\hline Ficus sp. 7 & Moraceae & - & syconium & - & 10 & 0.08 & $1^{*}$ \\
\hline Pseudolmedia oxyphyllaria & Moraceae & tree & drupe & - & 10 & 0.08 & $10^{*}$ \\
\hline Dendropanax arboreus & Araliaceae & tree & berry & - & 5 & 0.04 & $7,5^{*}$ \\
\hline Ficus sp. 6 & Moraceae & - & syconium & - & 5 & 0.04 & $<1^{*}$ \\
\hline sp. 8 & - & - & - & - & 4 & 0.03 & - \\
\hline Cissus sp. 1 & Vitaceae & vine & berry & - & 3 & 0.02 & $9^{*}$ \\
\hline Ficus sp. 8 & Moraceae & & syconium & - & 3 & 0.02 & $4^{*}$ \\
\hline sp. 4 & - & - & - & - & 3 & 0.02 & - \\
\hline Ocotea sp. 1 & Lauraceae & tree & drupe & - & 2 & 0.02 & $15^{*}$ \\
\hline sp. 5 & - & - & - & - & 2 & 0.02 & - \\
\hline Coussapoa purpusii & Cercropiaceae & epiphyte & aggregate & - & 1 & 0.01 & $2^{*}$ \\
\hline Ficus sp. 5 & Moraceae & - & syconium & - & 1 & 0.01 & $2^{*}$ \\
\hline Inga sp. 1 & Fabaceae & tree & legume & - & 1 & 0.01 & 40 \\
\hline sp. 7 & - & - & - & - & 1 & 0.01 & $2^{*}$ \\
\hline Trichostigma octandrum & Phytolaccaceae & vine & drupe & - & 1 & 0.01 & $5^{*}$ \\
\hline $\begin{array}{l}\text { Total Species }=33 \\
\text { Total Seeds }\end{array}$ & & & & & 13,162 & & \\
\hline
\end{tabular}


diversity at Los Tuxtlas $\left(\mathrm{H}^{\prime}=1.59, \mathrm{E}_{\mathrm{H}}=0.57\right)$ than in Palenque $\left(\mathrm{H}^{\prime}=1.30, \mathrm{E}_{\mathrm{H}^{\prime}}=0.63\right)$. Six dung beetle species were associated with both howler monkey groups, and Sorenson's quotient for dung beetles was 0.50 . The most common beetle species associated with howler feces at Los Tuxtlas was Canthon femoralis (58.3\%; Table 4), and at PNP it was Copris laeviceps (56.6\%; Table 4). At Los Tuxtlas, most of the beetles captured were ball-rollers (75.1\%), while at PNP most were burrowers (80.8\%; Table 4). Also, at Los Tuxtlas $21.3 \%$ of the beetles collected were nocturnal and $78.7 \%$ were diurnal, while at PNP $62.6 \%$ were nocturnal and $37.4 \%$ were diurnal (Table 4 ).

\section{Discussion}

Our behavioral and fecal samples data suggest that $A$. palliata and A. pigra differ somewhat in seed dispersal patterns despite being closely related. Previous studies report that
A. palliata can incorporate between nine and 35 fruit species into its diet depending on the location, and in Los Tuxtlas, a year-long study documented 28 seed species in $A$. palliata feces (Estrada and Coates-Estrada 1991; Whencke et al. 2004). A. pigra utilizes 25 fruit species in fragmented forests in Belize, and a five-month study reported ten seed species in A. pigra feces in Guatemala (Marsh and Loiselle 2003; Ponce-Santizo and Andresen 2006). These data suggest that $A$. palliata is capable of consuming more seed species than the 18 documented in this study and that $A$. pigra consumes more seed species in PNP than in other locations. However, because this study directly compares the two species in similar forests during the same period of the year, the differences detected between $A$. palliata and $A$. pigra may indicate a potential distinction in plant-primate dynamics. Specifically, $A$. palliata appears to consume more mature fruit and disperse more total seeds while $A$. pigra appears to disperse a greater diversity of seeds.

Table 4. Dung beetle species collected in Los Tuxtlas (A. palliata) and Palenque (A. pigra). 60 traps were set in each site for 24 hours for a total of 1,440 trap hours at each site. Quantity of each beetle species is reported using the absolute number and the percent of total beetles collected in each site. Activity describes the time of day at which each species is active, and behavior describes fecal treatment.

\begin{tabular}{|c|c|c|c|c|}
\hline \multicolumn{5}{|l|}{ Alouatta palliata } \\
\hline Species & Activity & Behavior & Number & Percent \\
\hline Canthon femoralis & diurnal & ball-roller & 208 & 58.3 \\
\hline Copris laeviceps & nocturnal & burrower & 52 & 14.6 \\
\hline Canthon euryscelis & diurnal & ball-roller & 19 & 5.3 \\
\hline Deltochilum pseudoparile & nocturnal & ball-roller & 12 & 3.4 \\
\hline Onthophagus batesi & diurnal & burrower & 12 & 3.4 \\
\hline Canthon viridis vazquezi & diurnal & ball-roller & 11 & 3.1 \\
\hline Dichotomius satanis & nocturnal & burrower & 11 & 3.1 \\
\hline Neocanthidium martinezi & diurnal & ball-roller & 7 & 2.0 \\
\hline Onthophagus rhinolophus & diurnal & burrower & 7 & 1.0 \\
\hline Pseudocanthos perplexus & diurnal & ball-roller & 5 & 1.4 \\
\hline Canthidium aff ardens Bates & diurnal & burrower & 4 & 1.1 \\
\hline Canthon subhyalinus & diurnal & ball-roller & 3 & 0.8 \\
\hline Canthidium perceptible & diurnal & burrower & 2 & 0.6 \\
\hline Phanaeus chryseicollis & diurnal & ball-roller & 2 & 0.6 \\
\hline Canthon sp. & diurnal & ball-roller & 1 & 0.3 \\
\hline Copris lubgris & nocturnal & burrower & 1 & 0.3 \\
\hline Total & & & 357 & \\
\hline \multicolumn{5}{|l|}{ Alouatta pigra } \\
\hline Species & Activity & Behavior & Number & Percent \\
\hline Copris laeviceps & nocturnal & burrower & 56 & 56.6 \\
\hline Onthophagus vatesi & diurnal & burrower & 19 & 19.2 \\
\hline Canthon euryscelis & diurnal & ball-roller & 15 & 15.2 \\
\hline Dichotomius satanis & nocturnal & burrower & 4 & 4.0 \\
\hline Canthon femoralis & diurnal & ball-roller & 2 & 2.0 \\
\hline Copris lubgris & nocturnal & burrower & 1 & 1.0 \\
\hline Deltochilum gibbosum & nocturnal & ball-roller & 1 & 1.0 \\
\hline Phanaeus endymion & diurnal & ball-roller & 1 & 1.0 \\
\hline Total & & & 99 & \\
\hline
\end{tabular}


Differences in patterns of range-use and daily travel between the two howler groups also likely result in the production of different seed shadows (sensu Clark et al. 2005). Since both groups dispersed similar amounts of seeds per day, but the $A$. palliata group utilized a larger home range and day range than the $A$. pigra group, the seed shadow produced by the $A$. palliata group is likely less dense than that produced by the $A$. pigra group. These behavioral differences are unlikely to be a result of group size since group size in these species appears to be dictated by social constraints and not by food availability (Chapman and Pavelka 2005; Cowlishaw and Dunbar 2000; Van Belle and Estrada 2008). Similarly, because territory overlap among groups was minimal, these patterns are likely to remain constant across the entire territory. During the high-fruit season, seed dispersal patterns also appear to differ between howler species with regard to associated secondary dispersers. Previous research in the continuous forest of Los Tuxtlas described 20 dung beetle species associated with $A$. palliata, and a study of $A$. pigra in Guatemala documented 29 dung beetle species (Estrada and Coates-Estrada 1991; PonceSantizo and Andresen 2006). However, our data reveal a larger and more diverse dung beetle population associated with the $A$. palliata group than the $A$. pigra group, which may indicate a higher probability of secondary dispersal for seeds dispersed in $A$. palliata feces between February and May. Furthermore, most seeds dispersed by ball-rollers are less than $3 \mathrm{~mm}$ in length (Estrada et al. 1993; Vulinec et al. 2006). The $A$. palliata group was associated with more ball-rollers and dispersed fewer large seeds than the $A$. pigra group, and the $A$. pigra group was associated with more burrowers and dispersed more large seeds than the $A$. palliata group. Therefore, the effectiveness of seed dispersal by each howler species may depend on the interaction of seed size and secondary dispersal by dung beetles. The association of more diurnal dung beetles with the $A$. palliata group and more nocturnal dung beetles with the $A$. pigra group likely also influences patterns of secondary seed dispersal since a large proportion of diurnal dung beetles are ball-rollers which may move seeds up to $5 \mathrm{~m}$ from the initial deposit site while a large proportion of nocturnal dung beetles are burrowers which bury seeds on-site (Slade et al. 2007; Vulinec and Lambert 2009).

The subtle differences in howler seed dispersal behavior and associated dung beetle assemblages described in this study suggest an important distinction between black and mantled howler monkeys as seed dispersers. Further investigation of these differences in more groups of each species may broaden our understanding of how closely related primate species differing in associated secondary seed dispersal agents, among other features (e.g. body size and group size), may also differ in their contribution to the maintenance of plant diversity in their habitats. The participation of distinct dung beetle communities in processing the feces produced by each howler group during the high-fruit season also highlights the importance of dung beetles as secondary dispersers (Nichols et al. 2008). Recent studies have shown that the stability of this interface is altered by human-induced forest fragmentation and habitat isolation, which cause local declines in size or extinctions of primate and dung beetle populations (Andresen 2002; Estrada and Coates-Estrada 2002; Nichols et al. 2008; Ponce-Santizo and Andresen 2006). Such changes may result in significant modifications in patterns of recovery and distribution for many forest plant species. These modifications will have a strong impact on the persistence of primates in fragmented landscapes and on human livelihood and merit further investigation.

\section{Acknowledgments}

K.R.A. acknowledges the Institute for International Education and the Comisión México-Estados Unidos para el Intercambio Educativo y Cultural (COMEXUS) (Fulbright Garcia-Robles), the National Geographic Conservation Trust (Young Explorers' Grants), and Dartmouth College (Reynold's Fellowship) for their support of this project. We are grateful to the Universidad Nacional Autónoma de Mexico (UNAM), specifically the Instituto de Biología, for its logistical support in both Palenque and Los Tuxtlas, and to the Comisión Nacional de Areas Naturales Protegidas (CONANP-PALENQUE) and the Secretaria del Medio Ambiente y Recursos Naturales (SEMARNAT) for granting access to our field sites in Mexico. We thank Shai Pilosof, Luis Alberto Pineda Alcazar, David Antonio Zuniuga, and David Muñoz for their assistance with data collection in the field.

\section{References}

Andresen, E. 2002. Dung beetles in a Central Amazonian rainforest and their ecological role as secondary seed dispersers. Ecol. Entomol. 27:257-270.

Chapman, C. A, and Pavelka MSM. 2005. Group size in folivorous primates: Ecological constraints and the possible influence of social factors. Primates 46(1):1-9.

Clark, C. J., Poulsen, J. R., Bolker, B. M., Connor, E. F., and Parker, V. T. 2005. Comparative seed shadows of bird-, monkey-, and wind-dispersed trees. Ecology 86(10):2684-2694.

Clark, C. J., Poulsen, J. R., and Parker V.T. 2001. The role of arboreal seed dispersal groups on the seed rain of a lowland tropical forest. Biotropica 33(4):606-620.

Cowlishaw, G., and Dunbar, R. 2000. Primate Conservation Biology: Chicago University Press.

Croat, T. B. 1978. Flora of Barro Colorado Island. Stanford: Stanford University Press.

Di Fiore, A., and Campbell, C. 2007. The Atelines: variations in ecology, behavior and social organization. In: Campbell, C., Fuentes, A., MacKinnon, K. C., Panger, M., and Bearder, S. K., editors. Primates in Perspective. New York: Oxford University Press. p 155-186.

Estrada, A. E. 1984. Resource use by howler monkeys (Alouatta palliata) in the rain forest of Los Tuxtlas, Veracruz, Mexico. Int. J. Primatol. 5:105-131. 
Estrada, A. E., Castellanos, L., Ibarra, A., Garcia Del Valle, Y., Munoz, D., Rivera, A., Franco, B., Fuentes, E., and Jimenez, C. 2002. Survey of the population of the black howler monkey, Alouatta pigra, at the Mayan site of Palenque, Chiapas, Mexico. Primates 44:51-58.

Estrada, A. E., and Coates-Estrada, R. 1984. Fruiting and frugivores at a strangler fig in the tropical rain forest of Los Tuxtlas, Mexico. J. Trop. Ecol. 2:349-357.

Estrada, A. E., and Coates-Estrada, R. 1991. Howling monkeys (Alouatta palliata), dung beetles (Scarabaeidae) and seed dispersal: ecological interactions in the tropical rain forest of Los Tuxtlas, Veracruz, Mexico. J. Trop. Ecol. 7:459-474.

Estrada, A. E., and Coates-Estrada, R. 2002. Dung beetles in continuous forest, forest fragments and in an agricultural mosaic habitat-island at Los Tuxtlas, Mexico. Biodivers. Conserv. 11:1903-1918.

Estrada, A. E., Halffter, G., Coates-Estrada, R., and Meritt Jr., D. 1993. Dung beetles attracted to mammalian herbivore (Alouatta palliata Gray) and omnivore (Nasua narica Linneaus) dung in the tropical rain forest of Los Tuxtlas, Mexico. J. Trop. Ecol. 9:45-54.

Ford, S. M. 2006. The biogeographic history of Mesoamerican primates. In: Estrada, A. E., Garber, P. A., Pavelka, M. S., and Luecke, L., editors. New Perspectives in the Study of Mesoamerican Primates: Distribution, Ecology, Behavior, and Conservation. New York: Springer. p 81-114.

Ford, S. M., and Davis, L. C. 1992. Systematics and body size: implications for feeding adaptations in New World monkeys. Am. J. Phys. Anthrop. 8:415-568.

Gross-Camp, N. D., Mulindahabi, F., and Kaplin, B. A. 2009. Comparing the dispersal of large-seeded tree species by frugivore assemblages in tropical montane forest in Africa. Biotropica 41(4):442-451.

Knogge, C., and Heymann, E. W. 2003. Seed dispersal by sympatric tamarins Saguinus mystax and Saguinus fuscicollis: Diversity and characteristics of plant species. Folia Primatol. 74(1):33-47.

Larsen, T. H., and Forsyth, A. 2005. Trap spacing and transect design for dung beetle biodiversity studies. Biotropica 37(2):322-325.

Link, A., and Di Fiore, A. 2006. Seed dispersal by spider monkeys and its importance in the maintenance of neotropical diversity. J. Trop. Ecol. 22(235-246).

Marsh, L. K., and Loiselle, B. A. 2003. Recruitment of black howler fruit trees in fragmented forests of northern Belize. Int. J. Primatol. 24(1):45-86.

Nichols, E., Spector, S., Louzada, J., Larsen, T., Amequita, S., and Favila, M. E. 2008. Ecological functions and ecosystem services provided by Scarabaeinae dung beetles. Biol. Conserv. 141(6):1461-1474.

Nunez-Iturri, G., Olsson, O., and Howe, H. F. 2008. Hunting reduces recruitment of primate-dispersed trees in Amazonian Peru. Biol. Conserv. 141(6):1536-1546.

Pavelka, M. S. M., and Knopff, K. H. 2004. Diet and activity in black howler monkeys (Alouatta pigra) in southern Belize: Does degree of frugivory influence activity level? Primates 45(2):105-111.
Ponce-Santizo, G., and Andresen, E. 2006. Effects of different levels of habitat disturbance on the fate of primatedispersed seeds in southern Mexico. Int. J. Primatol. 27:129.

Rylands, A. B., Groves, C. P., Mittermeier, R. A., CortesOrtiz, L., and Hins, J. J. H. 2006. Taxonomy and distributions of Mesoamerican primates. In: Estrada, A. E., Garber, P. A., Pavelka, M. S., and Luecke, L., editors. New Perspectives in the Study of Mesoamerican Primates: Distribution, Ecology, Behavior, and Conservation. New York: Springer. p 29-79.

Slade, E. M., Mann, D. J., Villanueva, J. F., and Lewis, O. T. 2007. Experimental evidence for the effects of dung beetle functional group richness and composition on ecosystem function in a tropical forest. J. Anim. Ecol. 76:1094-1104.

Stevenson, P. R., and Aldana, A. M. 2008. Potential effects of ateline extinction and forest fragmentation on plant diversity and composition in the western Orinoco basin, Columbia. Int. J. Primatol. 29:365-377.

Stevenson, P. R., Castellanos, M. C., Pizzaro, J. C., and Garavito, M. 2002. Effects of seed dispersal by three ateline monkey species on seed germination at Tinigua National Park, Columbia. Int. J. Primatol. 23(6):1187-1204.

Stoner, K. E., Riba-Hernandez, P., Vulinec, K., and Lambert, J.E. 2007. The role of mammals in creating and modifying seedshadows in tropical forests and some possible consequences of their elimination. Biotropica 39(3):316-327.

Van Belle, S., and Estrada, A. E.. 2008. Group size and competition influence male and female reproductive success in black howler monkeys (Alouatta pigra). Am. J. Primatol. 70:1-7.

Vander Wall, S. B., and Longland, W. S. 2004. Diplochory: are two seed dispersers better than one? Trends Ecol. Evol. 19(3):155-161.

Vulinec, K., and Lambert, J. E. 2009. Neutral and niche perspectives and the role of primates as seed dispersers: a case study from Rio Paratari, Brazil. In: Garber, P. A., Estrada, A. E., Bicca-Marques, J. C., Heymann, E. W., and Strier, K. B., editors. South American Primates, Developments in Primatology: Progress and Prospects. New York: Springer. p 321-340.

Vulinec, K., Lambert, J. E., and Mellow, D. J. 2006. Primate and dung beetle communities in secondary growth rain forests: implications for conservation of seed dispersal systems. Int. J. Primatol. 27(3):855-879.

Whencke, E. V., Valdez, C. N., and Dominguez, C. A. 2004. Seed dispersal and defecation patterns of Cebus capucinus and Alouatta palliata: consequences for seed dispersal effectiveness. J. Trop. Ecol. 20(5):535-543. 